\title{
Changes in endotracheal tube cuff pressure in mechanically ventilated adult patients
}

\author{
Asuka Motoyama ${ }^{1}$, Shota Asai ${ }^{1}$, Hiroyuki Konami ${ }^{1}$, Yuri Matsumoto ${ }^{1}$, Takuyo Misumi ${ }^{2}$, Hideaki Imanaka ${ }^{3 *}$ \\ and Masaji Nishimura ${ }^{4}$
}

\begin{abstract}
During mechanical ventilation, endotracheal tube cuff pressure should be maintained within proper range. We investigated the effect of frequent adjustment on cuff pressure in 27 mechanically ventilated patients. Cuff pressure was recorded every $2 \mathrm{~h}$ and was adjusted to $24 \mathrm{cmH}_{2} \mathrm{O}$ each time. We found that cuff pressure was decreased by $4.9 \pm 2.9 \mathrm{cmH}_{2} \mathrm{O}$ from the target value. Cuff pressure decreased to less than $20 \mathrm{cmH}_{2} \mathrm{O}$ in $45 \%$ of measurement occasions $2 \mathrm{~h}$ after adjusting it to $24 \mathrm{cmH}_{2} \mathrm{O}$.
\end{abstract}

Keywords: Cuff pressure, Endotracheal tube, Critically ill patients, Mechanical ventilation

\section{Correspondence}

To prevent gas leakage and aspiration, an endotracheal tube (ETT) with a cuff is generally used for mechanically ventilated patients. Because excessive cuff pressure decreases tracheal capillary perfusion, and insufficient cuff pressure leads to aspiration of oropharyngeal contents, [1-3] cuff pressure should be maintained within the proper range. Cuff pressure measurements are routinely taken every 8 to $24 \mathrm{~h}$, and during the interval, air inside the cuff may escape from the ETT cuff surface or through the pilot balloon valve. It remains unknown whether, through frequent adjustment, cuff pressure can be maintained within the target range. We prospectively collected 1,846 data points of cuff pressure from 27 adult patients receiving mechanical ventilation for longer than $48 \mathrm{~h}$ with cuffed ETTs, standard high-volume low-pressure cuff (Hi-Lo Mallinckrodt Medical, Dublin, Ireland). Nurses measured the cuff pressure every $2 \mathrm{~h}$ using a cuff inflator (Cuff Pressure Gauge, VBM Medizintechnik $\mathrm{GmbH}$, Baden-Württemberg, Germany) each time readjusting the pressure to $24 \mathrm{cmH}_{2} \mathrm{O}$. Ventilatory settings and body position remained unchanged during the 2-h interval. The study was approved by the hospital research board, which waived the requirement for informed consent for this observational study that was part of routine care.

\footnotetext{
* Correspondence: imanakah@clin.med.tokushima-u.ac.jp

${ }^{3}$ Emergency and Disaster Medicine, Tokushima University Hospital, 2-50-1

Kuramotocho, Tokushima, Tokushima Prefecture 770-8503, Japan

Full list of author information is available at the end of the article
}

Cuff pressure deviation from the target value $\left(24 \mathrm{cmH}_{2} \mathrm{O}\right)$ was $-4.9 \pm 2.9 \mathrm{cmH}_{2} \mathrm{O}$. Cuff pressure was below $20 \mathrm{cmH}_{2} \mathrm{O}$ in $45 \%$ of the measurements, below $24 \mathrm{cmH}_{2} \mathrm{O}$ in $93 \%$, and over $30 \mathrm{cmH}_{2} \mathrm{O}$ in $0.05 \%$ (Figure 1). Loss of cuff pressure is known to increase the risk of complications cuff pressure below $20 \mathrm{cmH}_{2} \mathrm{O}$ is associated with the development of ventilator-associated pneumonia $[1,2,4,5]$. Nseir et al. [3], measuring cuff pressure every $8 \mathrm{~h}$, found that cuff pressure was maintained within recommended range (20 to $30 \mathrm{cmH}_{2} \mathrm{O}$ ) in only $18 \%$ of patients, that it was lower than $20 \mathrm{cmH}_{2} \mathrm{O}$ at least once for $54 \%$ of patients, and that it was over $30 \mathrm{cmH}_{2} \mathrm{O}$ at least once for $73 \%$ of patients. In our study, the cuff tended to deflate, probably owing to different patient characteristics than in Nseir's study.

Because frequent readjustment did not prevent cuff pressure loss, we suspected that the measurement procedure itself might contribute to changes in cuff pressure. The air compressed in the cuff might escape to the measurement system during the connection procedure. Further study is needed to clarify the effect of measurement procedures in a broader variety of situations. Our study has several limitations: small population, varied observation time, and lack of evaluation of clinically significant outcomes. In conclusion, cuff pressure decreased to less than $20 \mathrm{cmH}_{2} \mathrm{O}$ in $45 \%$ of measurement occasions taken from critically ill patients $2 \mathrm{~h}$ after adjusting it to $24 \mathrm{cmH}_{2} \mathrm{O}$.

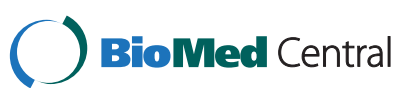




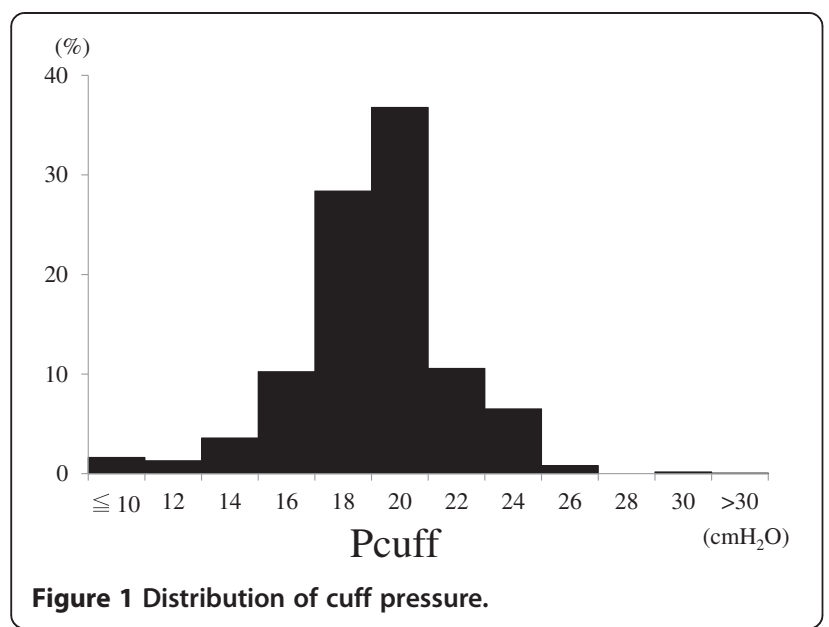

\section{Abbreviation}

ETT: endotracheal tube.

\section{Competing interests}

The authors declare that they have no competing interests.

\section{Authors' contributions}

AM, SA, HK, and YM established the design of the study, collected the data, and drafted the manuscript. TM participated in the design of the study and revised the manuscript. HI performed the statistical analysis and revised the manuscript. MN revised the manuscript. All authors read and approved the final manuscript.

\section{Author details}

${ }^{1}$ The University of Tokushima Graduate School, 2-50-1 Kuramotocho, Tokushima, Tokushima Prefecture 770-8503, Japan. ${ }^{2}$ Critical Care Medicine, Kobe University Hospital, 1-1 Rokkodaicho, Nada Ward, Kobe, Hyogo Prefecture 657-0013, Japan. ${ }^{3}$ Emergency and Disaster Medicine, Tokushima University Hospital, 2-50-1 Kuramotocho, Tokushima, Tokushima Prefecture 770-8503, Japan. ${ }^{4}$ Emergency and Critical Care Medicine, Tokushima University Hospital, 2-50-1 Kuramotocho, Tokushima, Tokushima Prefecture 770-8503, Japan.

Received: 8 August 2013 Accepted: 16 January 2014

Published: 31 January 2014

\section{References}

1. Sengupta P, Sessler DI, Maglinger P, Wells S, Vogt A, Durrani J, Wadhwa A: Endotracheal tube cuff pressure in three hospitals, and the volume required to produce an appropriate cuff pressure. BMC Anesthesiol 2004, $4: 8$

2. Sole ML, Su X, Talbert S, Penoyer DA, Kalita S, Jimenez E, Ludy JE, Bennett $M$ : Evaluation of an intervention to maintain endotracheal tube cuff pressure within therapeutic range. Am J Crit Care 2011, 20:109-117.

3. Nseir $\mathrm{S}$, Brisson $\mathrm{H}$, Marquette $\mathrm{CH}$, Chaud P, Di Pompeo C, Diarra M, Durocher A: Variations in endotracheal cuff pressure in intubated critically ill patients: prevalence and risk factors. Eur J Anaesthesiol 2009, 26:229-234.

4. Pneumatikos IA, Dragoumanis CK, Bouros DE: Ventilator-associated pneumonia or endotracheal tube-associated pneumonia? An approach to the pathogenesis and preventive strategies emphasizing the importance of endotracheal tube. Anesthesiology 2009, 110:673-680

5. Nseir S, Zerimech F, Fournier C, Lubret R, Ramon P, Durocher A, Balduyck M: Continuous control of tracheal cuff pressure and microaspiration of gastric contents in critically ill patients. Am J Respir Crit Care Med 2011, 184:1041-1047.

doi:10.1186/2052-0492-2-7

Cite this article as: Motoyama et al.: Changes in endotracheal tube cuff pressure in mechanically ventilated adult patients. Journal of Intensive Care 2014 2:7.

\section{Submit your next manuscript to BioMed Central and take full advantage of:}

- Convenient online submission

- Thorough peer review

- No space constraints or color figure charges

- Immediate publication on acceptance

- Inclusion in PubMed, CAS, Scopus and Google Scholar

- Research which is freely available for redistribution 